\title{
Thermochemical and structural changes in Jatropha curcas seed cake during torrefaction for its use as coal co-firing feedstock
}

Buddhike Neminda Madanayake ${ }^{\mathrm{a}}$, Suyin Gan ${ }^{\mathrm{a}}$, Carol Eastwick ${ }^{\mathrm{b}}$, Hoon Kiat $\mathrm{Ng}^{\mathrm{c}}$

${ }^{a}$ Department of Chemical and Environmental Engineering, The University of Nottingham Malaysia Campus, Jalan Broga, 43500 Semenyih, Selangor Darul Ehsan, Malaysia.

${ }^{\mathrm{b}}$ Energy and Sustainability Research Division, Faculty of Engineering, The University of Nottingham, University Park, Nottingham NG7 2RD, UK.

${ }^{c}$ Department of Mechanical, Materials and Manufacturing Engineering, The University of Nottingham Malaysia Campus, Jalan Broga, 43500 Semenyih, Selangor Darul Ehsan, Malaysia.

*Corresponding author. Tel. +603 8924 8162; fax. +603 8924 8017. E-mail address: suyin.gan@nottingham.edu.my (S. Gan)

\footnotetext{
Abstract

Jatropha curcas seed cake is a viable feedstock for co-firing with coal as it has the advantages of being renewable, carbon-neutral and sourced from a versatile plant. Torrefaction, a mild pyrolysis treatment by heating in a $\mathrm{N}_{2}$ atmosphere, was investigated as a technique to improve the thermochemical properties of the biomass, primarily the higher heating value (HHV). The temperature and holding time were varied in the ranges of $200-300^{\circ} \mathrm{C}$ and 0-60 min, respectively, to form a 5-level full-
} 
factorial experimental matrix. An optimum envelope of torrefaction parameters was identified in the range of $<5 \mathrm{~min}$ at $>280^{\circ} \mathrm{C}$ to $>45 \mathrm{~min}$ at $220-250^{\circ} \mathrm{C}$ under a heating rate of $10^{\circ} \mathrm{C} / \mathrm{min}$. This results in an enhancement of the HHV from $24 \mathrm{MJ} / \mathrm{kg}$ to more than $27 \mathrm{MJ} / \mathrm{kg}$, which is within the range of coal, while maintaining an energy yield higher than $90 \%$. The relationships between the HHV and the proximate fixed carbon content as well as the elemental $\mathrm{CHO}$ content were also investigated. Through ${ }^{13} \mathrm{C}$ NMR (nuclear magnetic resonance) spectroscopy, hemicellulose was determined as the most volatile component, undergoing decomposition before $250^{\circ} \mathrm{C}$ while cellulose only degraded fully in the $250-300^{\circ} \mathrm{C}$ range and lignin decomposition spanned from $200^{\circ} \mathrm{C}$ to beyond $300^{\circ} \mathrm{C}$.

\section{Keywords}

Biomass; torrefaction; Jatropha curcas; co-firing; NMR

\section{Introduction}

The development of alternatives to replace fossil fuels as the primary global energy source is gaining recognition as an issue of utmost importance. The major drivers behind the move away from fossil fuels are emissions releases from fossil fuels combustion and the non-renewable nature of the fuels. The combustion of fossil fuels worldwide generates copious amounts of greenhouse gases in particular carbon dioxide which contribute to global warming. Meanwhile, the non-renewable nature of fossil fuels means that the fuel reserves are finite; some estimates have projected that coal would only last another century $[1,2]$. 
Among the various alternative energy technologies, biomass co-firing stands out since it allows for the use of existing infrastructure without extensive modifications. Biomass in itself has the advantages over fossil fuels of being relatively carbon-neutral over the entire life cycle and also being renewable if sourced from sustainable plantations. Biomass co-firing with coal provides an immediate and practical solution to mitigating coal usage since coal plants of several hundred MW can be utilised in contrast to the 20-100 MW capacity of current biomass-only plants; the initial capital costs of building new plants are also avoided and biomass co-firing is considered one of the least costly alternative energy sources $[3,4]$. Co-firing also has the added advantage over coal of having enhanced ignition characteristics [5], and the flexibility over biomass-only plants of being less affected by seasonal availability of biomass [6].

There is a large variation in properties within the different types of biomass, and these can also vary widely from those of coal. It is this variation that is responsible for the technical constraints on co-firing. Closing this gap between the properties would diminish the need for specialised handling and combustion equipment, and would allow a higher proportion of biomass to be used in the co-firing blend [7]. The properties in question are thermochemical as well as physical - biomass has a higher moisture content, lower energy density and different grindability characteristics compared to coal [8-10].

Therefore, it is imperative to investigate pre-treatment techniques which would overcome some of the unfavourable characteristics of biomass and hence bring its behaviour closer to that of coal. One such technique is torrefaction, which involves a non-combustive mild pyrolysis reaction which occurs when the biomass is heated in an inert atmosphere (typically $\mathrm{N}_{2}$ ) to a temperature between $200^{\circ} \mathrm{C}$ and $300^{\circ} \mathrm{C}[11]$. 
Torrefaction increases the calorific value of the biomass, and this is one of most important benchmarks of the process; this in turn has a positive effect on the energy density of the biomass [12]. The process inevitably reduces the moisture content of the fuel, but also has the effect of making it more hydrophobic, i.e. its susceptibility to absorb moisture is reduced $[13,14]$. In addition to this, torrefaction has been shown to alleviate the poor grindability of biomass, which is an important outcome since it allows a uniform particle size distribution in the coal-biomass blend to be attained using existing milling/handling systems $[15,16]$.

Jatropha curcas is a species of shrub which is gaining recognition as a potential source of renewable energy in the form of biodiesel, as evidenced by the increasing number of Jatropha plantations that have been set up in (sub)tropical regions worldwide for this purpose [17]. The plant has a number of features that make it an appealing proposition as a bioresource - it can grow in annual rainfall conditions up to $1500 \mathrm{~mm}$, is able to withstand extended periods of drought [18] and is resistant to most pests [19], as well as grows and propagates rapidly [20]. Furthermore, its toxicity ensures a lack of competition with the food industry, which is an issue faced by sources of bioenergy such as palm oil and sugar cane [21]. Due to its adaptability to tropical and arid conditions, it is found natively and in plantations in Central America, Africa, India, China and Southeast Asia [22].

The primary driver behind current interest in Jatropha curcas is biodiesel production using the oil from the seeds. To date, there have been many studies on the utilisation of Jatropha curcas oil as biodiesel feedstock. However, the oil content of the seed is typically less than $40 \%$, and only $60-80 \%$ of this is extracted using conventional mechanical methods [23-25]. It follows then that the solid residue left after oil 
extraction (seed cake) still amounts to a significant amount of biomass, and a useful quantity of bioenergy could potentially be extracted from this waste product via cofiring. Nevertheless, co-firing of this seed cake is liable to the aforementioned complications due to potential differences in properties with coal.

There is a substantial gap in the research with respect to comprehensive characterisation, subsequent pre-treatment and evaluation of Jatropha curcas seed cake as a viable feedstock for combustion and/or co-firing. With the increasing recognition of Jatropha seed oil as a viable biodiesel feedstock, an investigation into utilising the resulting seed cake in this manner would be a worthwhile undertaking. This study investigates the upgrading of certain fuel properties of Jatropha curcas seed cake via torrefaction, to increase its viability for co-firing. In addition to the thermochemical changes such as the proximate and ultimate composition and higher heating value (HHV), ${ }^{13} \mathrm{C}$ nuclear magnetic resonance (NMR) spectroscopy is used to investigate the structural changes taking place during the torrefaction process.

\section{Materials and methods}

\subsection{Material}

Jatropha curcas seeds were provided by ACGT Sdn. Bhd. (Malaysia). They were dried for $24 \mathrm{~h}$ in an oven at $105^{\circ} \mathrm{C}$, and double wrapped in large plastic bags before shipping to Nottingham, UK. $55 \mathrm{~kg}$ of the seeds were sent to an external facility (Statfold Seed Oil Ltd.) for oil extraction using an expeller press. $48.5 \mathrm{~kg}$ of solid residue (seed cake) were obtained, corresponding to an oil yield of $12 \%$. This is lower than the oil yield of $28-40 \%$ reported in the literature $[19,26,27]$. The seed cake 
appeared to consist of two distinct components - hard, dark, rod-like structures in a soft, oily, loose soil-like matrix. The latter comprised approximately $3 / 4$ by weight of the total seed cake, and was the primary focus of this study.

\subsection{Torrefaction experimental matrix}

A 5-level full-factorial (triplicated) design of experiment was used. The tested torrefaction temperatures were $200^{\circ} \mathrm{C}, 225^{\circ} \mathrm{C}, 250^{\circ} \mathrm{C}, 275^{\circ} \mathrm{C}$ and $300^{\circ} \mathrm{C}$, while the tested holding times used were $0 \mathrm{~min}, 15 \mathrm{~min}, 30 \mathrm{~min}, 45 \mathrm{~min}$ and $60 \mathrm{~min}$. The run order was randomised using Minitab 17 statistical software, which was also used for the subsequent data analysis. Including the replicates, a total of 75 torrefaction runs were carried out.

\subsection{Torrefaction methodology}

Torrefaction of the seed cake was carried out using a horizontal tube furnace (HTF). The HTF used was a TSHH 11/90/457 model manufactured by Elite Thermal Systems. It is a split-type furnace with a tube diameter of $90 \mathrm{~mm}$ and a heated zone length of 457 $\mathrm{mm}$, which can reach a maximum temperature of $1100^{\circ} \mathrm{C}$. A quartz reactor tube with an internal diameter of $60 \mathrm{~mm}$ was placed within the furnace. End seals were fitted to the two open ends of the reactor tube, and a $\mathrm{N}_{2}$ gas supply was connected to one end. A rotameter enabled the gas flow rate to be controlled.

For each torrefaction run, $25 \mathrm{~g}( \pm 0.5 \mathrm{~g})$ was measured into a ceramic "weighing boat". The weighing boat was placed in the middle of the reactor tube and both ends of the tube were sealed using rubber bungs. The $\mathrm{N}_{2}$ supply was switched on and set to 2 $\mathrm{L} / \mathrm{min}$. After the $\mathrm{N}_{2}$ flow had been running for $5 \mathrm{~min}$ (to ensure that $\mathrm{O}_{2}$ is purged out of the reactor tube), the furnace was switched on. For each run, a constant ramp of 
$10^{\circ} \mathrm{C} / \mathrm{min}$ was used until the required torrefaction temperature was reached, followed by an isothermal period for the necessary holding time.

Immediately after the run was completed, the controller switches off the furnace and the hood of the furnace was opened to accelerate cooling. When the temperature readout reached $100^{\circ} \mathrm{C}$, the $\mathrm{N}_{2}$ supply was switched off and the sample was removed from the reactor tube. The sample was reweighed after it had cooled down to room temperature, and transferred to an airtight plastic bag for storage until subsequent analyses were carried out. The post-run procedure was standardised across all runs regardless of torrefaction temperature and holding time, since the pyrolysis process would continue to occur at the elevated temperatures during the cooling phase.

The mass yield following each torrefaction run was calculated using Eqn 1.

$$
\text { mass yield }=\frac{\text { final mass }}{\text { initial mass }} \times 100 \% \quad \text { Eqn } 1
$$

\subsection{Proximate analysis}

Thermogravimetric analysis (TGA) was used to determine the proximate composition of the seed cake, i.e. the moisture, volatile matter (VM), fixed carbon (FC) and ash content. The fundamental concept behind this technique is that the biomass sample undergoes mass loss in several consecutive stages as it is heated. These stages correspond to the different proximate components of the biomass being lost (moisture, VM, FC in that order), with the residual mass being the ash content. The TGA unit used was a TA Instruments Q500. 
The TGA runs employed a thermal profile which was constructed based on the British Standards guidelines for proximate analysis of biomass (BS EN 14774, BS EN 15148 , BS EN 14775). Under a $\mathrm{N}_{2}$ flow of $100 \mathrm{ml} / \mathrm{min}$, the sample was heated to $105^{\circ} \mathrm{C}$ at $10^{\circ} \mathrm{C} / \mathrm{min}$, held at that temperature for $40 \mathrm{~min}$, and then further heated to $905^{\circ} \mathrm{C}$ at $20^{\circ} \mathrm{C} / \mathrm{min}$. After an isothermal period at $905^{\circ} \mathrm{C}$ for $7 \mathrm{~min}$, the sample was cooled to $550^{\circ} \mathrm{C}$ at $20^{\circ} \mathrm{C} / \mathrm{min}$. Following this, the gas supply was switched to air flowing at 100 $\mathrm{ml} / \mathrm{min}$, and the sample was held at $550^{\circ} \mathrm{C}$ for $120 \mathrm{~min}$.

Seven samples of untorrefied biomass were subjected to the TGA to determine the mean proximate composition, while each torrefied sample was analysed once and the mean proximate composition calculated from the triplicate torrefaction runs.

\subsection{Calorimetry}

An IKA C5000 bomb calorimeter was used to measure the higher heating value (HHV). The untorrefied biomass was measured three times and the mean calculated, while each torrefied sample was measured once and the mean calculated using the values from the triplicate torrefaction runs.

The energy yield was calculated using Eqn 2:

$$
\text { energy yield }=\frac{H H V \text { of torrefied sample } x \text { final mass }}{H H V \text { of raw sample } x \text { initial mass }} \times 100 \%
$$

\subsection{Ultimate analysis}

The ultimate analysis was carried out in line with the relevant British Standards guidelines (BS EN 15104). A Thermo Scientific FlashEA 1112 elemental analyser was used for the measurement. The instrument consists of a furnace where the solid sample undergoes complete combustion in the presence of oxygen. Elemental C, H, N, S are 
oxidised to $\mathrm{CO}_{2}, \mathrm{H}_{2} \mathrm{O}, \mathrm{NO}_{\mathrm{x}}, \mathrm{SO}_{2}$, and the $\mathrm{NO}_{\mathrm{x}}$ is subsequently reduced to $\mathrm{N}_{2}$. The gases are then passed through a chromatographic column. Integration is performed on the resulting chromatogram to determine the percentage by weight of $\mathrm{C}, \mathrm{H}, \mathrm{N}, \mathrm{S}$. The $\mathrm{O}$ content can then be calculated by difference.

The analysis was performed on untorrefied and torrefied biomass. There were five replicates for the untorrefied biomass. With respect to the torrefied biomass, three samples for each temperature-time combination were analysed (for temperatures $200^{\circ} \mathrm{C}$, $250^{\circ} \mathrm{C}, 300^{\circ} \mathrm{C}$ and holding times $0 \mathrm{~min}, 30 \mathrm{~min}, 60 \mathrm{~min}$ ), i.e. the replicates in this case illustrate any variation between torrefaction runs carried out under identical conditions.

The moisture content of each sample, determined earlier by TGA, was used to calculate the $\mathrm{C}, \mathrm{H}, \mathrm{N}$, content on dry basis, by using the following equations:

$$
\begin{gathered}
C_{d r y}=C_{\text {measured }} \times \frac{100}{100-M} \\
H_{d r y}=\left(H_{\text {measured }}-\frac{M}{8.937}\right) \times \frac{100}{100-M} \\
N_{\text {dry }}=N_{\text {measured }} \times \frac{100}{100-M}
\end{gathered}
$$$$
\text { Eqn } 3
$$$$
\text { Eqn } 4
$$

where $\mathrm{M}$ is the moisture content.

The $\mathrm{O}$ content (dry basis) was then calculated using the following equation, based on the assumption that the $\mathrm{C}, \mathrm{H}, \mathrm{N}, \mathrm{O}$, moisture and ash content add up to unity.

$$
O_{d r y}=100-C_{d r y}-H_{d r y}-N_{d r y}-A
$$

where $\mathrm{A}$ is the ash content as determined by TGA. 


\section{7. ${ }^{13} \mathrm{C}$ Nuclear magnetic resonance (NMR) spectroscopy}

Solid-state ${ }^{13} \mathrm{C}$ NMR spectroscopy was conducted on untorrefied and selected torrefied samples. Three samples of untorrefied biomass, and three samples each from biomass torrefied at three temperatures $\left(200^{\circ} \mathrm{C}, 250^{\circ} \mathrm{C}, 300^{\circ} \mathrm{C}\right.$ all at $\left.60 \mathrm{~min}\right)$ were analysed for a total of 12 runs. A high-power cross polarisation (CP) sequence was used along with proton decoupling on a Bruker Avance 200 NMR instrument. The resonance

frequency for ${ }^{13} \mathrm{C}$ was $50 \mathrm{MHz}$. The sample was spun at approximately $5 \mathrm{kHz}$ and 2500 scans were accumulated for each run. Tetrakis(trimethylsilyl)silane (TKS), which has a chemical shift of $3.5 \mathrm{ppm}$, was used with each sample run for calibration.

\section{Results and discussion}

\subsection{Biomass characterisation}

The mean measured properties of the untreated biomass are shown in Table 1 . The mean HHV is calculated from triplicate measurements. The proximate and ultimate analyses are based on 7 replicate runs. The standard deviation (SD) and coefficient of variation $(\mathrm{CV})$ are also shown. The $\mathrm{CV}$ is the $\mathrm{SD}$ expressed as a percentage of the mean. Since the mean values for each element vary significantly, the CV provides a more useful representation of the relative variability.

Among the proximate composition, the moisture content has the largest CV. Since the mean measured moisture levels are relatively low, even a variation which is small in absolute terms (a range of $0.96 \% \mathrm{wt}$ ) results in a relatively large $\mathrm{CV}$. This justifies the use of dry ash-free (DAF) basis when presenting the VM and FC content data since it 
omits the variability introduced by the moisture content. This is reflected in the relatively low CV obtained for the DAF VM and DAF FC data.

With respect to the dispersion of the ultimate analysis data, the $\mathrm{CV}$ is lowest for $\mathrm{C}$ (although this can partly be attributed to its relatively high mean value). The moderately high $\mathrm{CV}$ for $\mathrm{O}$ is expected since the dry basis $\mathrm{O}$ content is calculated using five variables $(\mathrm{C}, \mathrm{H}, \mathrm{N}$, moisture, ash), and hence the dispersion present in each of these variables has an effect on the calculated value. However, the highest CV by a significant margin was for the $\mathrm{N}$ content. A possible explanation is that different parts of the seed would have a wide variation in $\mathrm{N}$ content due to the presence/absence of proteins in them, which contain a significant proportion of N. Even after milling and mixing, this variation would present itself as inhomogeneity within the seed cake. Table 2 shows the measured $\mathrm{C}, \mathrm{H}, \mathrm{N}$ along with their corresponding $\mathrm{CV}$ for both the untreated seed cake and 2,5-Bis(5-tert-butyl-2-benzo-oxazol-2-yl)thiophene (BBOT), which is the reference material used for calibration of the instrument. The measured value of the BBOT deviates from the reference value specified by its manufacturer by $0.2 \%$ or less, and its $\mathrm{CV}$ is below $1 \%$. This confirms the accuracy and precision of the measurement technique for the ultimate analysis, leaving the inhomogeneity of the seed cake as the most plausible explanation for the variation in measured values.

\subsection{Mass yield, HHV, energy yield}

Fig. 1 shows the interaction effects of the torrefaction temperature and holding time on the mean mass yield, HHV and energy yield. The error bars represent the standard errors of the mean values. 
The mass yield decreases with increasing torrefaction intensity, i.e. increasing torrefaction temperature and holding time. This would be the expected observation, since more moisture and volatiles would be lost as the sample is exposed to a higher temperature for a longer time. It can be seen that discounting the 0 min holding time, the mass yield shows an approximately linear decrease with increasing temperature; as the temperature is increased from $200^{\circ} \mathrm{C}$ to $300^{\circ} \mathrm{C}$, the mass yield drops by an average of $35 \%$ in these runs. A linear regression model for the non- 0 min mass yield data resulted in an $\mathrm{R}^{2}$ value of $94.1 \%$. For the holding time of 0 min however, a different trend is seen. Here, the mass yield decreases at a much lower rate than the non- 0 min runs as the temperature is increased. However, the trend is non-linear with the rate increasing at higher torrefaction temperatures. The 0 min holding time reflects the torrefaction occurring during the heating and cooling segments of each run, since the "holding time" variable only represents the isothermal residence time. Since a constant heating rate was used for all runs, the sample is exposed to elevated temperatures for a longer time when the torrefaction temperature is higher. This would result in a greater mass loss due to moisture of volatiles, and result in a curve with an increasing negative gradient.

The HHV responds inversely to the mass yield, i.e. the HHV increases with escalating torrefaction intensity. This is in fact a primary driver for the consideration of torrefaction as a biomass pre-treatment technique. This increase has been explained in literature on the basis that torrefaction results in a loss of VM. VM lost from biomass consists of hydrogen gas and light hydrocarbons which have a low $\mathrm{C}$ content compared to $\mathrm{H}[28]$. Hence, there is a substantially greater amount of $\mathrm{H}$ and $\mathrm{O}$ lost during torrefaction than there is $\mathrm{C}[29,30]$. This is reflected in the increased FC and elemental C content observed in the proximate and ultimate analyses of torrefied Jatropha which 
will be discussed subsequently in Sections 3.3 and 3.4. There is a reduction in the H/C and $\mathrm{O} / \mathrm{C}$ ratios, and since the $\mathrm{C}-\mathrm{H}$ and $\mathrm{C}-\mathrm{O}$ bond energies are lower than that of $\mathrm{C}-\mathrm{C}$, this results in an increase in the calorific value of the biomass [31,32].

Excluding the 0 min runs, the HHV shows an approximate direct proportionality to the temperature up to $\sim 275^{\circ} \mathrm{C}$. A linear regression fit in this segment resulted in an $\mathrm{R}^{2}$ value of $89.2 \%$. The curves flatten beyond this temperature; this effect becomes more pronounced as the holding time increases. The mean HHV (taking into account all holding times excluding $0 \mathrm{~min}$ ) increases by only $0.64 \%$ when the temperature is increased from $275^{\circ} \mathrm{C}$ to $300^{\circ} \mathrm{C}$. Hence, using temperatures in excess of $275^{\circ} \mathrm{C}$ would not be beneficial as far as the HHV is concerned.

Table 3 shows how the enhancement of the HHV of Jatropha curcas seed cake compares with that of some other types of biomass [33-37]. All results are at conditions of $250^{\circ} \mathrm{C}$ and $30 \mathrm{~min}$. Although other variables such as heating rate and particle size make a direct comparison less meaningful, the results in Table 3 illustrates the range of possible outcomes of the torrefaction process on different biomass types at seemingly similar conditions - the HHV enhancement varies from $1 \%$ to as much as $30 \%$ while that of Jatropha is $16 \%$. Thus, the HHV enhancement obtained for Jatropha is within the range of outcomes reported in the literature.

A regression analysis of the measured $\mathrm{HHV}$ in terms of the mass loss - obtained by subtracting the mass yield from unity - showed a linear fit with an $\mathrm{R}^{2}$ value of $91.9 \%$. The following regression equation was obtained:

$$
H H V(M J / k g)=24.55+(0.15 x \text { mass loss }(\%))
$$


Similar linear trends were reported by Almeida et al. [38] and Peng et al. [39] following the torrefaction of softwood and Eucalyptus wood and bark, respectively . The corresponding regression coefficients obtained by Peng et al. [38] were 19.48 and 0.15, which are similar to those presented in Eqn 7. Carrying out the regression using the mass loss instead of the mass yield results in an equation in which the constant is approximately equal to the $\mathrm{HHV}$ of the untorrefied biomass, which is $24.06 \mathrm{MJ} / \mathrm{kg}$ (see Table 1). This feature of the regression equation was highlighted by Almeida et al. [39].

The energy yield is a function of the mass yield and the HHVs of the untorrefied and torrefied biomass, as shown in Eqn 2; the energy yield is directly proportional to both the mass yield and the HHV of the torrefied biomass since the HHV of the untorrefied biomass is considered a constant. As the torrefaction intensity is increased, the drop in the energy yield implies that the enhancement in the HHV is insufficient to compensate for the decreasing mass yield. For all non- 0 holding times, the energy yield drops at a higher rate as the temperature is increased. When the holding time is $0 \mathrm{~min}$, the trend shows a higher degree of irregularity; the energy yield shows a marked drop only when the torrefaction temperature is increased beyond $275^{\circ} \mathrm{C}$. The mean energy yield (calculated from all non-0 holding times) decreases by $5.5 \%$ when the temperature is increased from $200^{\circ} \mathrm{C}$ to $250^{\circ} \mathrm{C}$, but drops by a further $14.6 \%$ when the temperature is increased to $300^{\circ} \mathrm{C}$.

Table 4 shows the results from an ANOVA (analysis of variance) test that was carried out on the mass and energy yields as well as the HHV. The 0 min holding time was excluded from the analysis. A p-value greater than 0.05 indicates that a factor or interaction between factors has a statistically significant effect on the response, i.e. mass yield, HHV, energy yield. For all three responses, the interaction between temperature 
and time is not significant, i.e. the effect of the temperature on the response is not dependent on the holding time, and vice versa. This is reflected in Fig. 1, where the non-0 min curves are approximately parallel to each other.

The p-values for the temperature and time (main effects) are all 0.000. This indicates that when considered independently, both factors have a significant effect on the responses. This independent effect is illustrated in the main effects plots for the three responses in Fig. 2, which show the mean response for each value of one factor, irrespective of the other factor. A striking feature of the plots is that the temperature has a substantially larger effect than the holding time; this is true for all three responses, i.e. the mass yield, HHV and energy yield. This observation is corroborated by the F-values in Table 4, since a larger F-value is indicative of a more dominant factor.

\subsection{Fixed carbon (FC) content}

The proximate analysis from the TGA yielded the moisture, VM, FC and ash contents of the samples. The VM and FC measurements were converted to DAF basis so to eliminate the variability introduced by the moisture and ash content. Since the DAF VM and DAF FC are by definition inversely proportional to each other (since the four components of the proximate analysis should add up to unity), only the DAF FC is presented.

Fig. 3 shows the variation of the DAF FC with torrefaction temperature. Torrefaction at higher intensities causes the DAF FC to increase. At the median holding time of $30 \mathrm{~min}$, the DAF FC content increases by $65 \%$. At the extreme holding times of 0 min and $60 \mathrm{~min}$, it increases by $25 \%$ and $90 \%$, respectively. At higher temperatures, there is a greater loss in the VM; it can be postulated that this is due to the initiation of 
certain decomposition pathways which require higher activation energies. As stated in Section 3.2, the lost volatiles consist mostly of low-C molecules, and hence a lower fraction of $\mathrm{C}$ is lost from the biomass compared to other elements. This would lead to an increase in the FC content.

A method to estimate the HHV of solid fuels using their proximate analysis can prove to be useful tool; proximate analysis using TGA is a common initial characterisation of a fuel while accurate measurement of the HHV requires additional equipment. There have been several past studies which have derived expressions for carrying this out [40-43]. In the present case, four regression models were applied to investigate the relationship between the DAF FC content and HHV, and the predicted $\mathrm{R}$-square (pred- $\mathrm{R}^{2}$ ) value and standard error of regression ( $\mathrm{S}$ value) were used to determine the efficacy of each model. The higher pred- $\mathrm{R}^{2}$ value is desirable, as it is an indicator of how well the model can predict a removed observation. Compared to the standard $R^{2}$ value, the pred- $R^{2}$ prevents over-fitting noise into the model. The $S$ value indicates the average distance from the observed points to the fitted line, and a lower value is preferred in this case. Table 5 shows the pred- $\mathrm{R}^{2}$ and $\mathrm{S}$ values corresponding to the four models, along with the equation coefficients (a, b, c, d). The four models were:

- Linear:

$$
\mathrm{HHV}=\mathrm{a}+\mathrm{b}^{*}(\text { DAF_FC })
$$

Eqn 8

- Linear logarithmic:

$\mathrm{HHV}=\mathrm{a}+\mathrm{b} * \ln \left(\mathrm{DAF} \_\mathrm{FC}\right)$

Eqn 9

- Quadratic:

$$
\mathrm{HHV}=\mathrm{a}+\mathrm{b}^{*}(\text { DAF_FC })+\mathrm{c}^{*}(\text { DAF_FC })^{2} \text { Eqn } 10
$$

- Cubic:

$$
\mathrm{HHV}=\mathrm{a}+\mathrm{b}^{*}(\text { DAF_FC })+\mathrm{c} *(\text { DAF_FC })^{2}+
$$

$$
\mathrm{d}^{*}\left(\mathrm{DAF} \_\mathrm{FC}\right)^{3}
$$


The quadratic and cubic functions possess the best pred- $\mathrm{R}^{2}$ and $\mathrm{S}$ values. However, the quadratic function would be the more desirable option since it contains one less term and is the less complex equation of the two.

\subsection{Ultimate analysis}

Fig. 4 shows the variation with torrefaction temperature of $\mathrm{C}, \mathrm{H}, \mathrm{N}, \mathrm{O}$ content $(\%$ by weight, dry basis) of the torrefied seed cake. The error bars illustrate the standard errors associated with the calculated means. A clear pattern cannot be identified in the variation of the $\mathrm{N}$ and $\mathrm{H}$ content. There is a significant overlap in the error bars due to the large variation between the replicates. A similarly large variability was observed in the $\mathrm{N}$ content of the untorrefied biomass and an explanation for this was discussed earlier in Section 3.1.

This overlap is also observed in the $\mathrm{C}$ and $\mathrm{O}$ content, albeit to a lesser degree. However, some distinct trends can be observed in this case. With increasing torrefaction intensity, the $\mathrm{C}$ content increases while the $\mathrm{O}$ content decreases. As the temperature is increased from $200^{\circ} \mathrm{C}$ to $300^{\circ} \mathrm{C}$, there is an approximately linear increase in the $\mathrm{C}$ content by $14 \%$, while the $\mathrm{O}$ content decreases by $33 \%$. The trend in $\mathrm{C}$ content confirms previous findings of increasing FC content (from the proximate analysis obtained from TGA, Section 3.3), and can be traced to the loss of low-C volatiles during the torrefaction process. However, the reducing $\mathrm{O}$ content indicates that the volatiles lost also contain a significant proportion of $\mathrm{O}$ in their molecular structure. Another observation is that the torrefaction temperature has a more pronounced effect on both the $\mathrm{C}$ and $\mathrm{O}$ content than the holding time; there is substantial overlapping between the $30 \mathrm{~min}$ and 60 min curves. This observation is expected since it is a trend that has been observed throughout the study (mass and energy yields, HHV, DAF FC content). 
Table 6 shows the p-values from the ANOVA test. These values confirm that the torrefaction temperature and holding time have a statistically significant effect on the $\mathrm{C}$ and $\mathrm{O}$ content. The high p-values for the temperature and time factors for $\mathrm{H}$ and $\mathrm{N}$ further strengthen the conclusion that the dispersion among the data is too great to extract a statistically reliable trend from it. Meanwhile, the high p-values for the temperature*time interaction for $\mathrm{C}$ and $\mathrm{O}$ indicate a statistically insignificant interaction between the two factors, i.e. a change in the holding time does not change how the temperature influences the response ( $\mathrm{C}$ or $\mathrm{O}$ content). This is reflected in the relatively parallel gradients observed in Fig. 4(a) and 4(d).

Fig. 5(a) and 5(b) are van Krevelen diagrams which show the $\mathrm{H} / \mathrm{C}$ ratio plotted against the $\mathrm{O} / \mathrm{C}$ ratio; the torrefied and untorrefied seed cakes have been included, grouped by temperature and holding time in Fig. 5(a) and 5(b), respectively. These diagrams have been used in literature as a tool to characterise the thermochemical properties of fuels. Fig. 5(c) shows the typical positions of biomass and coal on such a diagram. Coal occupies the lower-left section of the diagram, and it is desirable for the biomass in question to be in this vicinity since it indicates similar thermochemical properties to coal (which would be beneficial for the ultimate aim of co-firing). It can be seen from Fig. 5(a) that increasing the torrefaction temperature causes the points to shift towards the lower-left direction, which is the required outcome of the torrefaction process. However, Fig. 5(b) shows a wide dispersion of points when grouped according to holding time, further reinforcing the conclusion that holding time has a less significant effect on the properties of the biomass than the torrefaction temperature. 


\section{5. ${ }^{13} \mathrm{C}$ NMR spectroscopy}

Fig. 6 shows the NMR spectra for the untorrefied and torrefied biomass, with that of one sample selected from each level of torrefaction. Assignment of the peaks was done using the existing literature while taking into account the fact that an uncertainty of \pm 2 ppm can exist. The sharp peak at $3.5 \mathrm{ppm}$ is caused by the standard TKS which was used for calibration of the spectrum.

A typical ${ }^{13} \mathrm{C}$ biomass spectrum can be broadly grouped into four sections [44]:

- $>160$ ppm : carboxylic C

- $110 \mathrm{ppm}-160 \mathrm{ppm}$ : aromatic C

- 46 ppm - 110 ppm : carbohydrate C

- $\quad<46$ ppm : aliphatic C

The peaks at approximately $21 \mathrm{ppm}$ and $171 \mathrm{ppm}$ are assigned to acetyl groups in hemicellulose $[11,45,46]$. The group of peaks between $62 \mathrm{ppm}$ and $103 \mathrm{ppm}$ are due to C1 to C6 atoms, predominantly of cellulose although hemicellulose also makes a contribution $[11,47]$. The cluster of peaks between $110 \mathrm{ppm}$ and $160 \mathrm{ppm}$ are attributed to aromatic rings in lignin $[47,48]$ while the broad shoulder at approximately $52-56$ ppm is assigned to the methoxyl group of lignin [47,49]. In the untreated biomass, cellulose appears to be the most abundant component, followed by hemicellulose and lignin.

Following torrefaction at the lowest temperature of $200^{\circ} \mathrm{C}$, degradation can be observed across the spectrum. The most significant losses are of the hemicellulose-only peaks (acetyl groups) and the carbohydrate region. Due to the overlap of hemicellulose and cellulose signals in the carbohydrate region $(62-110 \mathrm{ppm})$, the extent of individual 
cellulose and hemicellulose decomposition cannot be determined with certainty; however, Neupane et al. [11] attributed most of this decomposition to hemicellulose . A flattening is observed in the $110-160$ ppm region, indicating that lignin decomposition has occurred; methoxyl lignin has also undergone degradation. Despite these changes in intensity, the overall shape of the spectrum is still comparable to that of the untorrefied biomass.

After torrefaction at $250^{\circ} \mathrm{C}$, more significant changes have occurred. The hemicellulose has almost completely decomposed, although a degree of cellulose is still present. The most noteworthy observations are the appearance of two new broad peaks centred around $26 \mathrm{ppm}$ (aliphatic region) and 125-126 ppm (aromatic region). Overall, lignin decomposition has not progressed drastically since the $200^{\circ} \mathrm{C}$ torrefaction.

It is evident that torrefaction at $300^{\circ} \mathrm{C}$ has changed the structure of the biomass comprehensively. Both hemicellulose and cellulose have undergone complete decomposition. The spectrum is now dominated by the aforementioned two broad peaks; these represent the aliphatic and aromatic products of the torrefaction reaction, since their growth occurred parallel to the decomposition of the cellulose peaks. Although not immediately evident due to the overlap by the aromatic product peak around $125-126 \mathrm{ppm}$, the shoulder at approximately $140 \mathrm{ppm}$ and the slight bump at approximately $54 \mathrm{ppm}$ indicates that the lignin has still not completely decomposed.

From this analysis, it can be seen that hemicellulose is the most volatile component present and undergoes significant decomposition between torrefaction temperatures of $200^{\circ} \mathrm{C}$ and $250^{\circ} \mathrm{C}$. Cellulose is comparatively more stable, and although it starts degrading below $250^{\circ} \mathrm{C}$, complete decomposition only occurs between $250^{\circ} \mathrm{C}$ and 
$300^{\circ} \mathrm{C}$. Lignin undergoes decomposition over a wide range of temperatures, starting from as low as $200^{\circ} \mathrm{C}$ and continuing beyond $300^{\circ} \mathrm{C}$. These results are in line with other

${ }^{13} \mathrm{C}$ NMR studies carried out on other types of torrefied biomass including bamboo [50], beech wood [51] and loblolly pine [11]. The phenomenon of decreasing aliphatic and aromatic signals under mild conditions, followed by the increase thereof at higher temperatures was also reported by Neupane et al. [11]. This study proposed that this was due to aliphatic and aromatic $\mathrm{C}-\mathrm{C}$ and $\mathrm{C}-\mathrm{H}$ bonds being formed from the decomposition products by way of polymerisation and recondensation products.

\subsection{Practical implications}

The key driver behind torrefaction in the context of this study is the enhancement of the HHV. Coal used in power plants would typically have a HHV in the range of 27-32 $\mathrm{MJ} / \mathrm{kg}$ [52]. To support co-firing, it would be desirable to bring the HHV of the biomass to within this range. A higher HHV also implies that the energy density is higher, and this is advantageous in terms of storage and transport. When carried out at higher intensities, the torrefaction process was able to increase the HHV of the Jatropha seed cake to $\sim 30 \mathrm{MJ} / \mathrm{kg}$. However, the energy yields at these torrefaction conditions are less than $80 \%$ (see Fig. 7(a) and 7(b)). A low energy yield would be undesirable from an energy efficiency standpoint and could potentially make the process economically unviable. Hence, the torrefaction conditions should be chosen so that neither the HHV nor the energy yield is excessively compromised.

Fig. 7(c) was generated by overlaying the selected regions of the two contour plots in Fig. 7(a) and 7(b), with an energy yield greater than $90 \%$ and a HHV greater than 27 $\mathrm{MJ} / \mathrm{kg}$. The unshaded region depicts the range of torrefaction conditions which would satisfy both these conditions. The possible combinations of torrefaction temperature and 
holding times range from $<5 \mathrm{~min}$ at $>280^{\circ} \mathrm{C}$ to longer holding times ( 45 to $60 \mathrm{~min}$ ) at lower temperatures $\left(220^{\circ} \mathrm{C}\right.$ to $\left.250^{\circ} \mathrm{C}\right)$. These guidelines are valid for the conditions under which the torrefaction was performed, most significantly under a heating rate of $10^{\circ} \mathrm{C} / \mathrm{min}$.

The cost of the torrefaction process in terms of energy required by the furnace and the cost of the $\mathrm{N}_{2}$ supply should also be taken into account in a practical implementation of the process. The cost implications of using low temperature/long holding time versus high temperature/short holding time have to be investigated further, and would be dependent on the torrefaction rig used. This would allow the desirable parameter range to be narrowed down further, and the process to be optimised in a more comprehensive manner. Measurement of energy expenditure was considered beyond the scope of this study, particularly because it is at a laboratory scale and any results thus obtained would not be scalable directly to a full-scale torrefaction plant. A few studies focusing on the economic aspects of torrefaction have been conducted in the recent past $[53,54]$. Typically, the energy cost of the torrefaction process is offset by the improvement in grindability and energy density which in turn reduce milling and transport costs. However, this would depend on a careful design and implementation of the system taking into account factors such as the transport distances, mode of transport and the energy source for the pre-treatment processes.

It is important to adopt a holistic approach when assessing the suitability of a certain type of biomass for co-firing. Torrefaction aims to improve the thermophysical and physical characteristics of the fuel. However, there are other considerations as well, chief among which is chemical composition of the biomass. The typically high inorganic content of biomass is one of the major detractors to biomass combustion as it 
is responsible for a host of ash-related problems. Leaching is touted as a pre-treatment option to mitigate these issues; the authors have previously carried out a study on applying this technique to Jatropha curcas seed cake [55]. Another aspect that has to be explored is the combustion behaviour of Jatropha curcas seed cake, including devolatilisation and char combustion characteristics. This is considered an avenue for future research.

\section{Conclusions}

The fundamental parameters used for the optimisation of the torrefaction process are the HHV and energy yield, which respond inversely to each other. An envelope of torrefaction conditions exists - ranging from $<5 \mathrm{~min}$ at $>280^{\circ} \mathrm{C}$ to $>45 \mathrm{~min}$ at $220^{\circ} \mathrm{C}$ $250^{\circ} \mathrm{C}$ when a heating rate of $10^{\circ} \mathrm{C} / \mathrm{min}$ is used - where a HHV greater than $27 \mathrm{MJ} / \mathrm{kg}$ can be obtained while maintaining an energy yield greater than $90 \%$. The increase in measured elemental $\mathrm{C}$ content and proximate DAF FC content corroborated the theoretical explanation for the increase in $\mathrm{HHV}$ as the torrefaction intensity was increased. The ${ }^{13} \mathrm{C}$ NMR analysis provided insight into the structural changes occurring during the torrefaction process, with hemicellulose proving to be the most volatile lignocellulosic component followed by cellulose and lignin. Complete decomposition of hemicellulose and cellulose occurred by $250^{\circ} \mathrm{C}$ and $300^{\circ} \mathrm{C}$, respectively, while lignin continued to decompose beyond $300^{\circ} \mathrm{C}$. Throughout the study, the torrefaction temperature was demonstrated to be a more dominant factor than the holding time. 


\section{Acknowledgements}

This work was supported by the Faculty of Engineering, University of Nottingham (UK and Malaysia) under the Engineering InterCampus PhD Scholarship. The authors would also like to thank ACGT Sdn. Bhd. (Malaysia) and Dr. Cheah Suan Choo for providing the Jatropha curcas seeds.

\section{References}

[1] Mohr SH, Wang J, Ellem G, Ward J, Giurco D. Projection of world fossil fuels by country. Fuel 2015;141:120-35. doi:10.1016/j.fuel.2014.10.030.

[2] Shafiee S, Topal E. When will fossil fuel reserves be diminished? Energy Policy 2009;37:181-9. doi:10.1016/j.enpol.2008.08.016.

[3] Bakis R. Alternative Electricity Generation Opportunities. Energy Sources, Part A Recover Util Environ Eff 2007;30:141-8. doi:10.1080/00908310600628362.

[4] Vassilev S V., Vassileva CG, Vassilev VS. Advantages and disadvantages of composition and properties of biomass in comparison with coal: An overview. Fuel 2015;158:330-50. doi:10.1016/j.fuel.2015.05.050.

[5] Gani A, Morishita K, Nishikawa K, Naruse I. Characteristics of co-combustion of low-rank coal with biomass. Energy \& Fuels 2005:1652-9.

[6] Agbor E, Zhang X, Kumar A. A review of biomass co- fi ring in North America 2014;40:930-43. doi:10.1016/j.rser.2014.07.195.

[7] Maciejewska A, Veringa H, Sanders J, Peteves SD. Co-firing of Biomass with Coal: Constraints and Role of Biomass Pre-treatment. 2006.

[8] Baxter L. Biomass-coal co-combustion: opportunity for affordable renewable energy. Fuel 2005;84:1295-302. doi:10.1016/j.fuel.2004.09.023.

[9] Demirbas A. Sustainable cofiring of biomass with coal. Energy Convers Manag 2003;44:1465-79.

[10] Veijonen K, Vainikka P, Järvinen T, Alakangas E. Biomass co-firing-an efficient way to reduce greenhouse gas emissions. VTT Process March 2003. 
[11] Neupane S, Adhikari S, Wang Z, Ragauskas a J, Pu Y. Effect of torrefaction on biomass structure and hydrocarbon production from fast pyrolysis. Green Chem 2015:2406-17. doi:10.1039/C4GC02383H.

[12] Chen W-H, Peng J, Bi XT. A state-of-the-art review of biomass torrefaction, densification and applications. Renew Sustain Energy Rev 2015;44:847-66. doi:10.1016/j.rser.2014.12.039.

[13] Felfli FF, Luengo CA, Suárez JA, Beatón PA. Wood briquette torrefaction. Energy Sustain Dev 2005;9:19-22. doi:10.1016/S0973-0826(08)60519-0.

[14] Peng JH, Bi HT, Lim CJ, Sokhansanj S. Study on density, hardness, and moisture uptake of torrefied wood pellets. Energy and Fuels 2013;27:967-74. doi:10.1021/ef301928q.

[15] Gil MV, García R, Pevida C, Rubiera F. Grindability and combustion behavior of coal and torrefied biomass blends. Bioresour Technol 2015;191:205-12. doi:10.1016/j.biortech.2015.04.117.

[16] Guijun W, Yonghao LUO, Jian D, Jianghong K, Yunliang Z, Wang G, et al. Pretreatment of biomass by torrefaction. Chinese Sci Bull 2011;56:1442-8. doi:10.1007/s11434-010-4143-y.

[17] Li Z, Lin B-L, Zhao X, Sagisaka M, Shibazaki R. System approach for evaluating the potential yield and plantation of Jatropha curcas L. on a global scale. Environ Sci Technol 2010;44:2204-9. doi:10.1021/es903004f.

[18] Openshaw K. A review of Jatropha curcas : an oil plant of unful ${ }^{\circledR}$ lled 2000;19.

[19] Pandey VC, Singh K, Singh JS, Kumar A, Singh B, Singh RP. Jatropha curcas: A potential biofuel plant for sustainable environmental development. Renew Sustain Energy Rev 2012;16:2870-83. doi:10.1016/j.rser.2012.02.004.

[20] Sujatha M, Reddy TP, Mahasi MJ. Role of biotechnological interventions in the improvement of castor (Ricinus communis L.) and Jatropha curcas L. Biotechnol Adv 2008;26:424-35. doi:10.1016/j.biotechadv.2008.05.004.

[21] Wever D-AZ, Heeres HJ, Broekhuis A a. Characterization of Physic nut (Jatropha curcas L.) shells. Biomass and Bioenergy 2012;37:177-87. doi:10.1016/j.biombioe.2011.12.014.

[22] Edrisi SA, Dubey RK, Tripathi V, Bakshi M, Srivastava P, Jamil S, et al. Jatropha curcas L.: A crucified plant waiting for resurgence. Renew Sustain Energy Rev 2015;41:855-62. doi:10.1016/j.rser.2014.08.082.

[23] Achten WM, Mathijs E, Verchot L, Singh VP, Aerts R, Muys B. Jatropha biodiesel fueling sustainability? Biofuels, Bioprod Biorefining 2007;1:283-91. doi:10.1002/bbb.39. 
[24] Fernández CM, Fiori L, Ramos MJ, Pérez Á, Rodríguez JF. Supercritical extraction and fractionation of Jatropha curcas L. oil for biodiesel production. $\mathbf{J}$ Supercrit Fluids 2015;97:100-6. doi:10.1016/j.supflu.2014.11.010.

[25] Subroto E, Manurung R, Heeres HJ, Broekhuis AA. Optimization of mechanical oil extraction from Jatropha curcas L. kernel using response surface method. Ind Crops Prod 2015;63:294-302. doi:10.1016/j.indcrop.2014.08.050.

[26] Ginwal HS, Rawat PS, Srivastava RL. Seed source variation in growth performance and oil yield of Jatropha curcas Linn. in central India. Silvae Genet 2004;53:186-92.

[27] Singh RN, Vyas DK, Srivastava NSL, Narra M. SPRERI experience on holistic approach to utilize all parts of Jatropha curcas fruit for energy. Renew Energy 2008;33:1868-73. doi:10.1016/j.renene.2007.10.007.

[28] Vassilev S V., Baxter D, Andersen LK, Vassileva CG. An overview of the chemical composition of biomass. Fuel 2010;89:913-33.

doi:10.1016/j.fuel.2009.10.022.

[29] Chen W, Kuo P-C. A study on torrefaction of various biomass materials and its impact on lignocellulosic structure simulated by a thermogravimetry. Energy 2010;35:2580-6. doi:10.1016/j.energy.2010.02.054.

[30] Chen W-H, Du S-W, Tsai C-H, Wang Z-Y. Torrefied biomasses in a drop tube furnace to evaluate their utility in blast furnaces. Bioresour Technol 2012;111:433-8. doi:10.1016/j.biortech.2012.01.163.

[31] McKendry P. Energy production from biomass (Part 1): Overview of biomass. Bioresour Technol 2002;83:37-46.

[32] Narvaez I, Orio A. Biomass gasification with air in an atmospheric bubbling fluidized bed. Effect of six operational variables on the quality of the produced raw gas. Ind Eng Chem Res 1996;5885:2110-20.

[33] Ohm T-I, Chae J-S, Kim J-K, Oh S-C. Study on the characteristics of biomass for co-combustion in coal power plant. J Mater Cycles Waste Manag 2015;17:24957. doi:10.1007/s10163-014-0334-y.

[34] Wannapeera J, Fungtammasan B, Worasuwannarak N. Effects of temperature and holding time during torrefaction on the pyrolysis behaviors of woody biomass. J Anal Appl Pyrolysis 2011;92:99-105. doi:10.1016/j.jaap.2011.04.010.

[35] Chen W-H, Hsu H-C, Lu K-M, Lee W-J, Lin T-C. Thermal pretreatment of wood (Lauan) block by torrefaction and its influence on the properties of the biomass. Energy 2011;36:3012-21. doi:10.1016/j.energy.2011.02.045. 
[36] Phanphanich M, Mani S. Impact of torrefaction on the grindability and fuel characteristics of forest biomass. Bioresour Technol 2011;102:1246-53. doi:10.1016/j.biortech.2010.08.028.

[37] Deng J, Wang G, Kuang J, Zhang Y, Luo Y. Pretreatment of agricultural residues for co-gasification via torrefaction. J Anal Appl Pyrolysis 2009;86:331-7. doi:10.1016/j.jaap.2009.08.006.

[38] Almeida G, Brito JO, Perré P. Alterations in energy properties of eucalyptus wood and bark subjected to torrefaction: the potential of mass loss as a synthetic indicator. Bioresour Technol 2010;101:9778-84. doi:10.1016/j.biortech.2010.07.026.

[39] Peng JH, Bi XT, Sokhansanj S, Lim CJ. Torrefaction and densification of different species of softwood residues. Fuel 2013;111:411-21. doi:10.1016/j.fuel.2013.04.048.

[40] Demirbas A. Calculation of higher heating values of biomass fuels. Fuel 1997;76:431-4.

[41] Nhuchhen DR, Abdul Salam P. Estimation of higher heating value of biomass from proximate analysis: A new approach. Fuel 2012;99:55-63. doi:10.1016/j.fuel.2012.04.015.

[42] Yin C-Y. Prediction of higher heating values of biomass from proximate and ultimate analyses. Fuel 2011;90:1128-32. doi:10.1016/j.fuel.2010.11.031.

[43] Sheng C, Azevedo JLT. Estimating the higher heating value of biomass fuels from basic analysis data. Biomass and Bioenergy 2005;28:499-507. doi:10.1016/j.biombioe.2004.11.008.

[44] Fründ R, Lüdemann H-D. 13C-NMR Spectroscopy of Lignins and Lignocellulosic Materials. Physico-Chemical Characterisation Plant Residues Ind. Feed Use, Dordrecht: Springer Netherlands; 1989, p. 110-7. doi:10.1007/978-94-009-1131-4_10.

[45] Li M-F, Li X, Bian J, Xu J-K, Yang S, Sun R-C. Influence of temperature on bamboo torrefaction under carbon dioxide atmosphere. Ind Crops Prod 2015;76:149-57. doi:10.1016/j.indcrop.2015.04.060.

[46] Sievers C, Marzialetti T, Hoskins TJC, Valenzuela Olarte MB, Agrawal PK, Jones CW. Quantitative solid state NMR analysis of residues from acid hydrolysis of loblolly pine wood. Bioresour Technol 2009;100:4758-65. doi:10.1016/j.biortech.2008.11.060.

[47] Bernardinelli OD, Lima MA, Rezende CA, Polikarpov I, deAzevedo ER. Quantitative 13C MultiCP solid-state NMR as a tool for evaluation of cellulose 
crystallinity index measured directly inside sugarcane biomass. Biotechnol Biofuels 2015;8:110. doi:10.1186/s13068-015-0292-1.

[48] Gilardi G, Abis L, Cass a. EG. Carbon-13 CP/MAS solid-state NMR and FT-IR spectroscopy of wood cell wall biodegradation. Enzyme Microb Technol 1995;17:268-75. doi:10.1016/0141-0229(94)00019-N.

[49] Park J, Meng J, Lim KH, Rojas OJ, Park S, Hun K. Transformation of lignocellulosic biomass during torrefaction. J Anal Appl Pyrolysis 2013;100:199-206. doi:10.1016/j.jaap.2012.12.024.

[50] Wen JL, Sun SL, Yuan TQ, Xu F, Sun RC. Understanding the chemical and structural transformations of lignin macromolecule during torrefaction. Appl Energy 2014;121:1-9. doi:10.1016/j.apenergy.2014.02.001.

[51] Melkior T, Jacob S, Gerbaud G, Hediger S, Le Pape L, Bonnefois L, et al. NMR analysis of the transformation of wood constituents by torrefaction. Fuel 2012;92:271-80. doi:10.1016/j.fuel.2011.06.042.

[52] Mardon SM, Hower JC. Impact of coal properties on coal combustion by-product quality: Examples from a Kentucky power plant. Int J Coal Geol 2004;59:15369. doi:10.1016/j.coal.2004.01.004.

[53] Agar D, Gil J, Sanchez D, Echeverria I, Wihersaari M. Torrefied versus conventional pellet production - A comparative study on energy and emission balance based on pilot-plant data and EU sustainability criteria. Appl Energy 2015;138:621-30. doi:10.1016/j.apenergy.2014.08.017.

[54] Topell Energy BV. Topell Torrefaction System 2015. http://www.topellenergy.com/technology/the-topell-torrefaction-system/.

[55] Madanayake BN, Gan S, Eastwick C, Ng HK. Leaching as a pretreatment process to complement torrefaction in improving co-firing characteristics of Jatropha curcas seed cake. Waste Biomass Valorization 2015:1-11. doi:10.1007/s12649-015-9467-z. 
Table 1. Characterisation results of untorrefied Jatropha curcas seed cake.

\begin{tabular}{cccc} 
& Mean & SD & CV (\%) \\
Moisture & $3.86 \% \mathrm{wt}$ & 0.45 & 11.74 \\
Dry ash & $4.44 \% \mathrm{wt}$ & 0.15 & 3.37 \\
DAF VM & $82.99 \% \mathrm{wt}$ & 1.17 & 1.43 \\
\hline DAF FC & $16.99 \% \mathrm{wt}$ & 1.18 & 6.47 \\
HHV & $24.06 \mathrm{MJ} / \mathrm{kg}$ & 0.13 & 0.52 \\
Dry C & $56.34 \% \mathrm{wt}$ & 0.57 & 1.00 \\
Dry H & $7.59 \% \mathrm{wt}$ & 0.39 & 5.13 \\
Dry N & $4.25 \% \mathrm{wt}$ & 1.13 & 26.60 \\
Dry O & $30.93 \% \mathrm{wt}$ & 2.12 & 6.86 \\
\hline
\end{tabular}


Table 2. Measured C, H, N content of untorrefied seed cake and BBOT reference material.

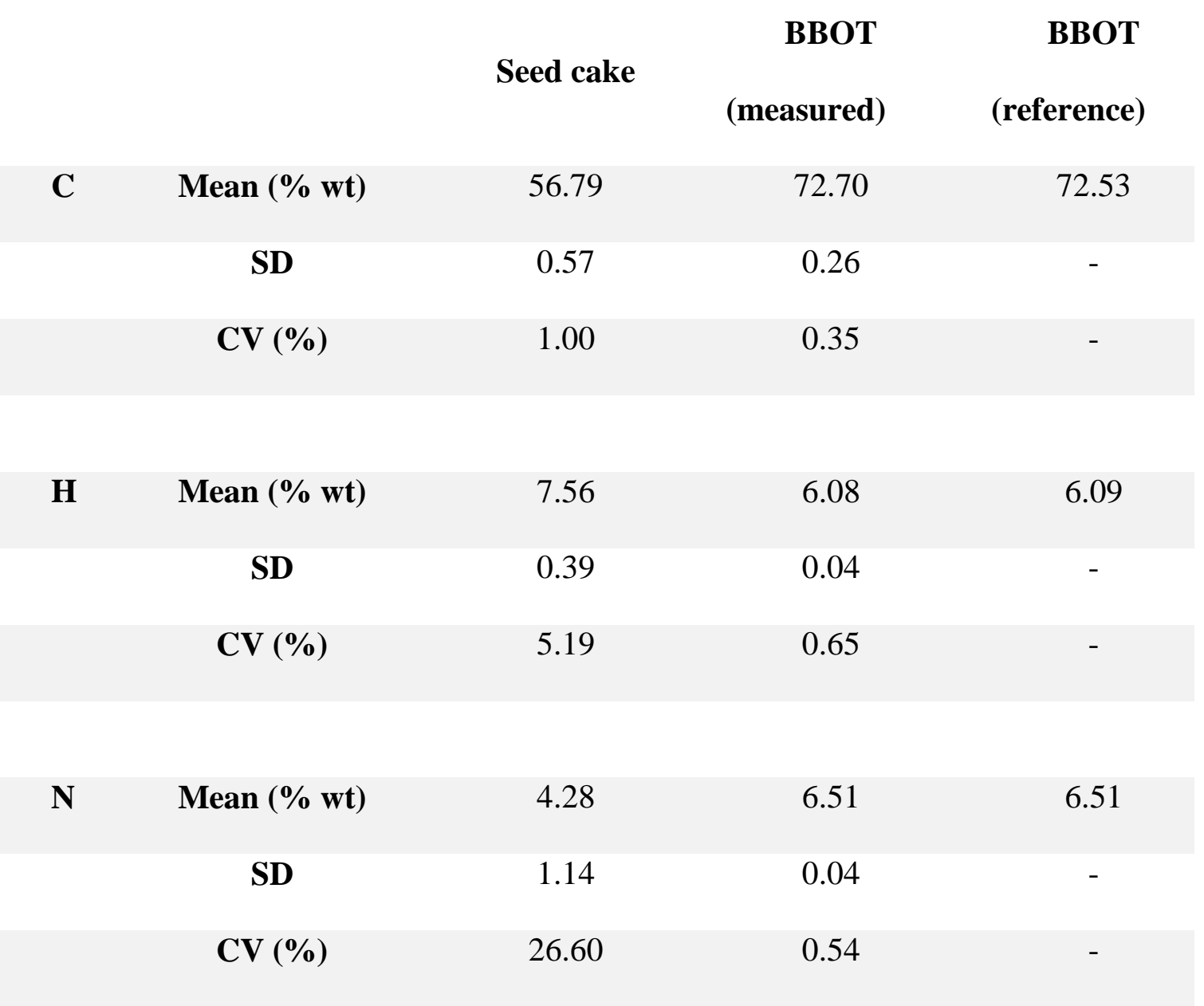


Table 3. Comparison of HHV enhancement obtained in recent torrefaction studies.

\section{Reference}

\section{Biomass}

\section{HHV}

\section{enhancement}

Current study

Jatropha curcas

$16 \%$

[33]

Waste wood

$2 \%$

[34]

Leucaena leucocephala (woody biomass)

$1 \%$

[35]

Lauan (woody biomass)

$30 \%$

[36]

Pine chips

$9 \%$

[36]

Logging residue

$13 \%$

[37]

Rice straw

$5 \%$

[37]

Rape stalk

$7 \%$ 
Table 4. p- and F-values from ANOVA test of mass yield, HHV and energy yield data.

\begin{tabular}{|c|c|c|c|c|c|}
\hline & \multicolumn{3}{|c|}{ p-value } & \multicolumn{2}{|c|}{ F-value } \\
\hline & temp & time & $\begin{array}{l}\text { temp*time } \\
\text { interaction }\end{array}$ & temp & time \\
\hline Mass yield & 0.000 & 0.000 & 0.221 & 1039.51 & 60.48 \\
\hline HHV & 0.000 & 0.000 & 0.060 & 305.33 & 14.43 \\
\hline Energy yield & 0.000 & 0.000 & 0.327 & 231.62 & 22.54 \\
\hline
\end{tabular}


Table 5. Coefficients and test statistics from regression analysis of HHV and DAF FC content.

$\begin{array}{crr}\text { Linear } & \text { Linear } & \text { Qubdratic } \\ & \text { logarithmic }\end{array}$

\begin{tabular}{|c|c|c|c|c|}
\hline pred-R ${ }^{2}$ & $79.98 \%$ & $82.69 \%$ & $83.77 \%$ & $83.62 \%$ \\
\hline $\mathbf{S}$ & 0.8834 & 0.8240 & 0.7968 & 0.7846 \\
\hline $\mathbf{a}$ & 20.30 & 3.723 & 12.80 & 26.11 \\
\hline b & 0.3046 & 7.587 & 0.9274 & -0.7096 \\
\hline c & - & - & -0.01219 & 0.05258 \\
\hline d & - & - & - & -0.0008260 \\
\hline
\end{tabular}


Table 6. p-values from ANOVA test of elemental dry $\mathrm{C}$, dry $\mathrm{H}$, dry $\mathrm{N}$ and dry $\mathrm{O}$.

$$
\text { p-value }
$$

temperature

time

temperature*ti

me interaction

C

0.000

0.000

0.747

H

0.012

0.114

0.009

$\mathbf{N}$

0.051

0.293

0.002

O

0.000

0.002

0.372 

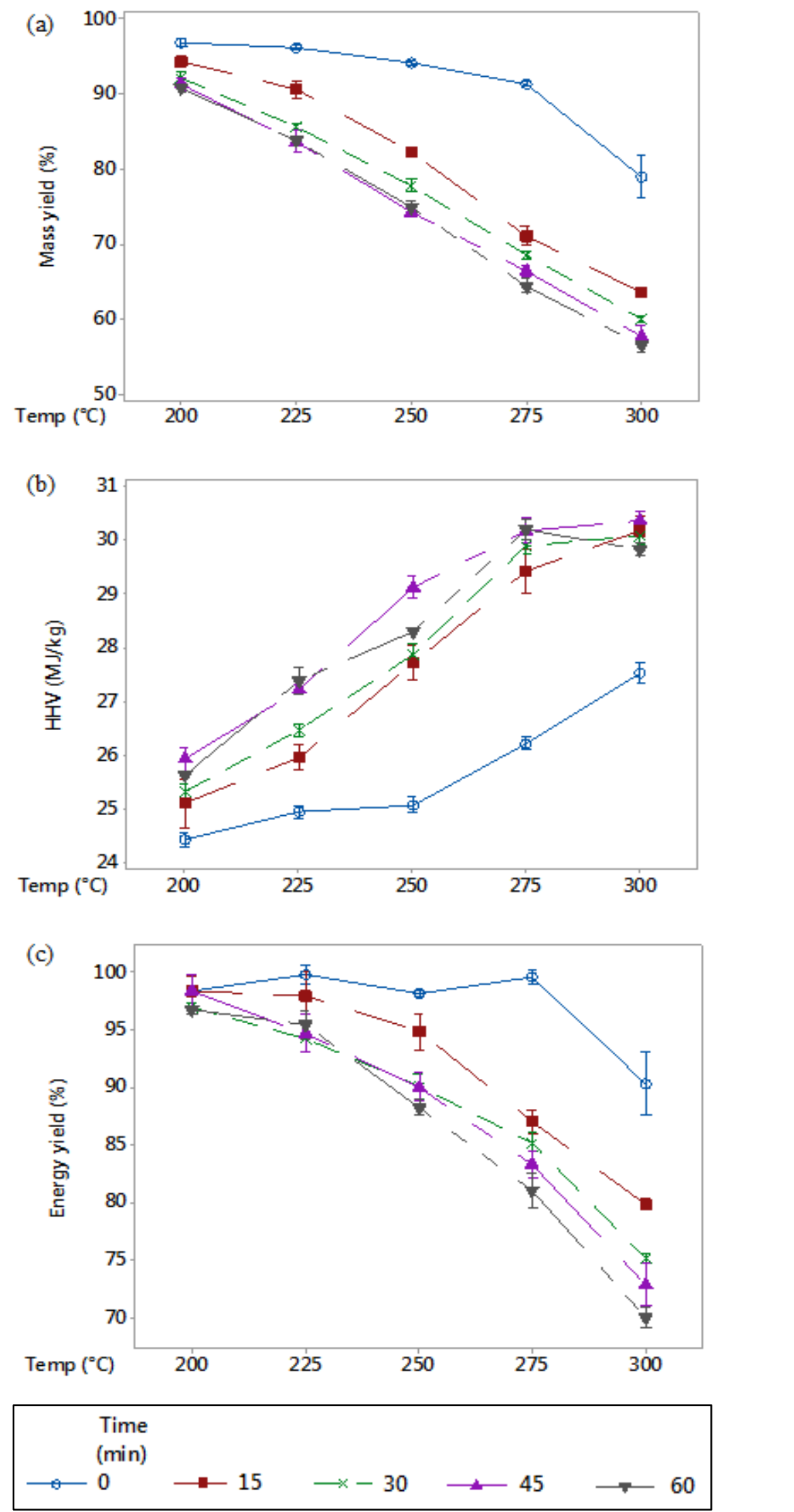

Fig. 1. Variation with torrefaction time of (a) mass yield, (b) HHV, (c) energy yield. 
(a)

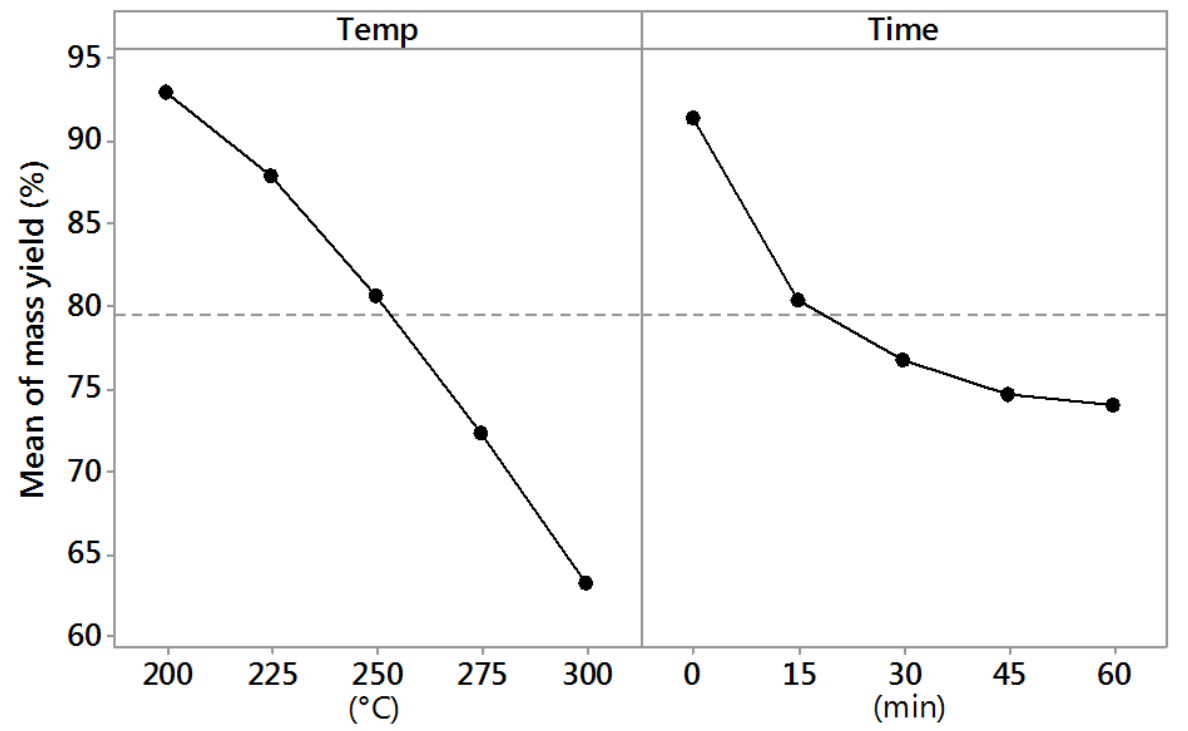

(b)
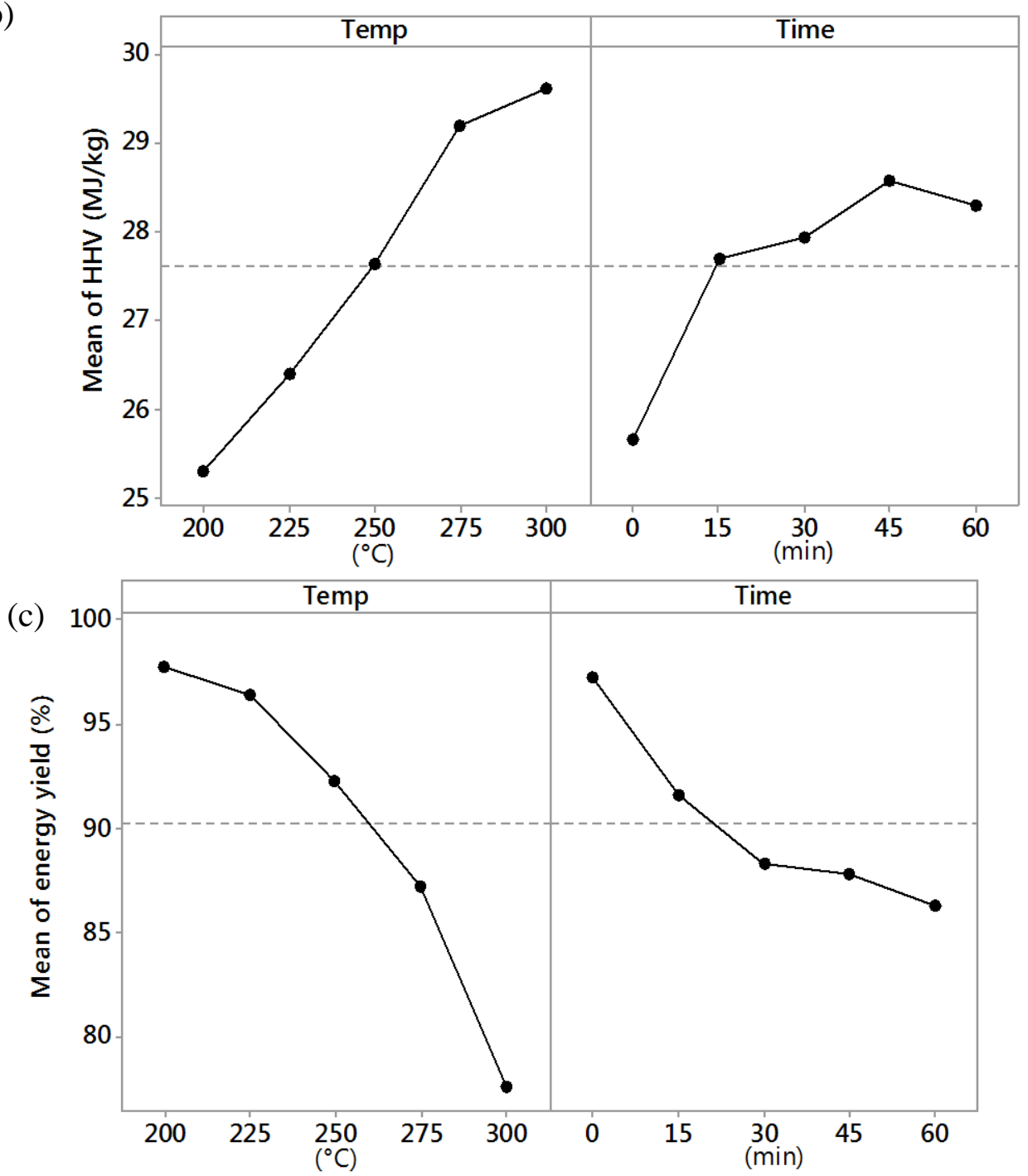

Fig. 2. Main effects plots of (a) mass yield, (b) HHV, (c) energy yield. 

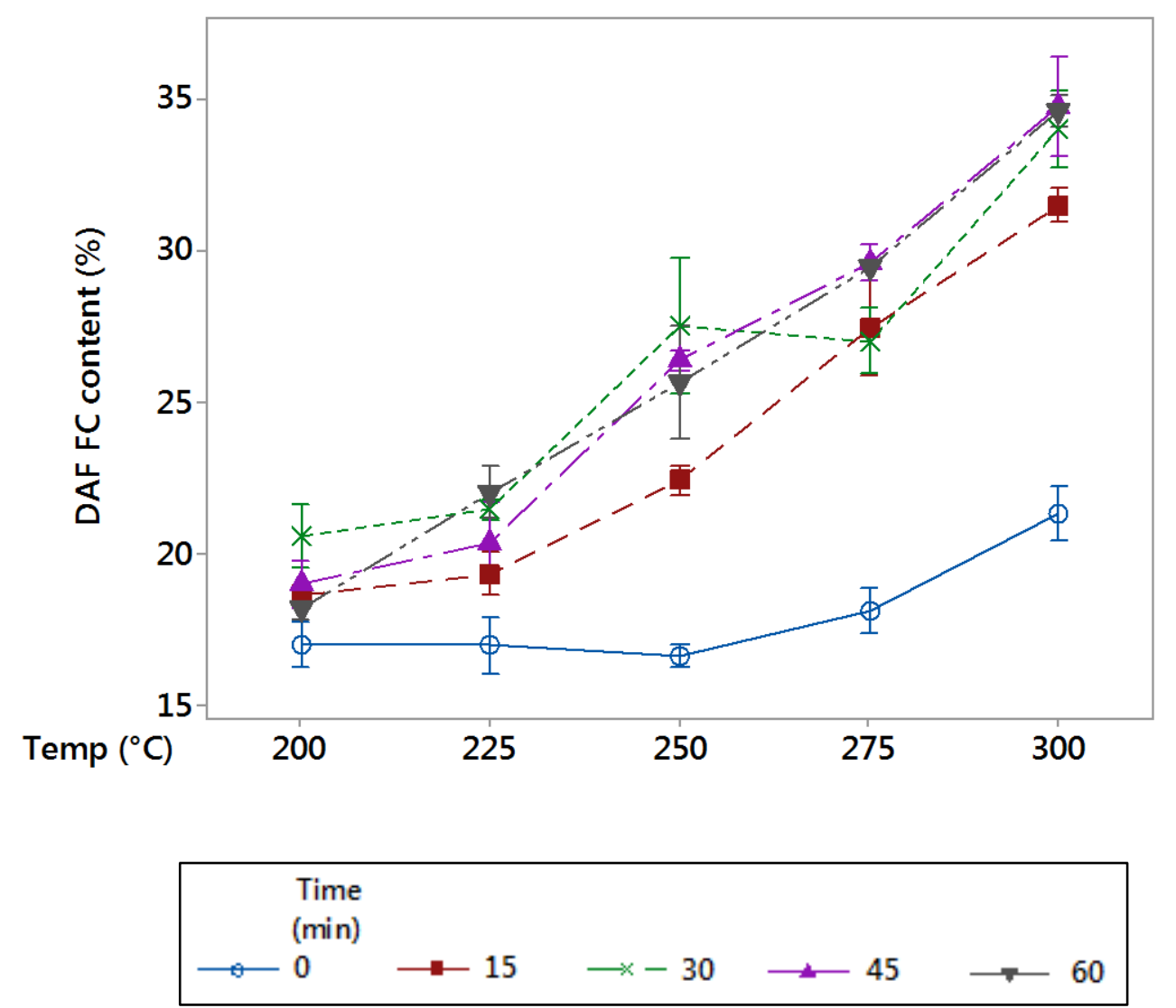

Fig. 3. Variation with temperature of DAF FC content (error bars indicate standard errors). 


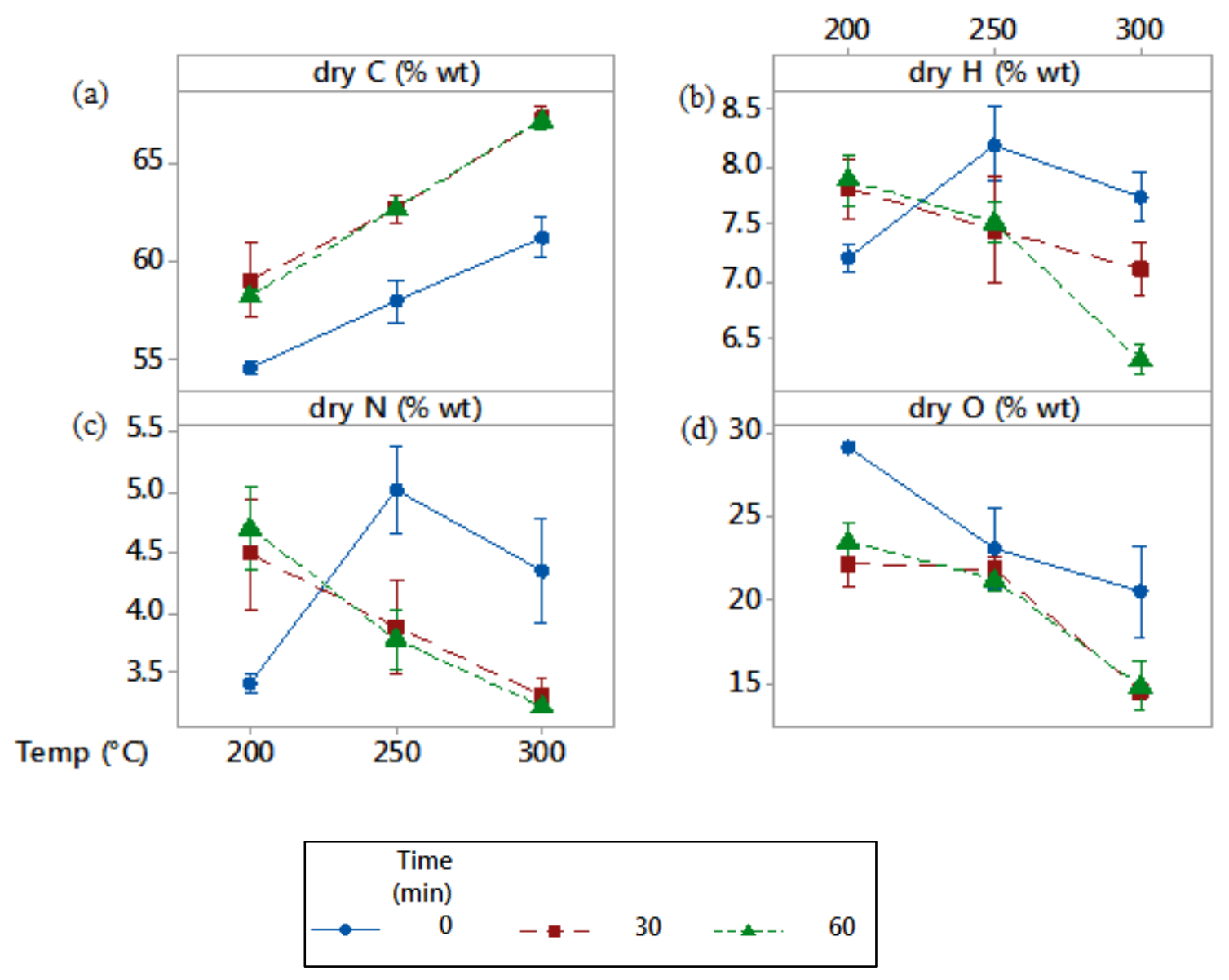

Fig. 4. Variation with temperature of elemental (a) dry C, (b) dry H, (c) dry N, (d) dry O. 
(a)

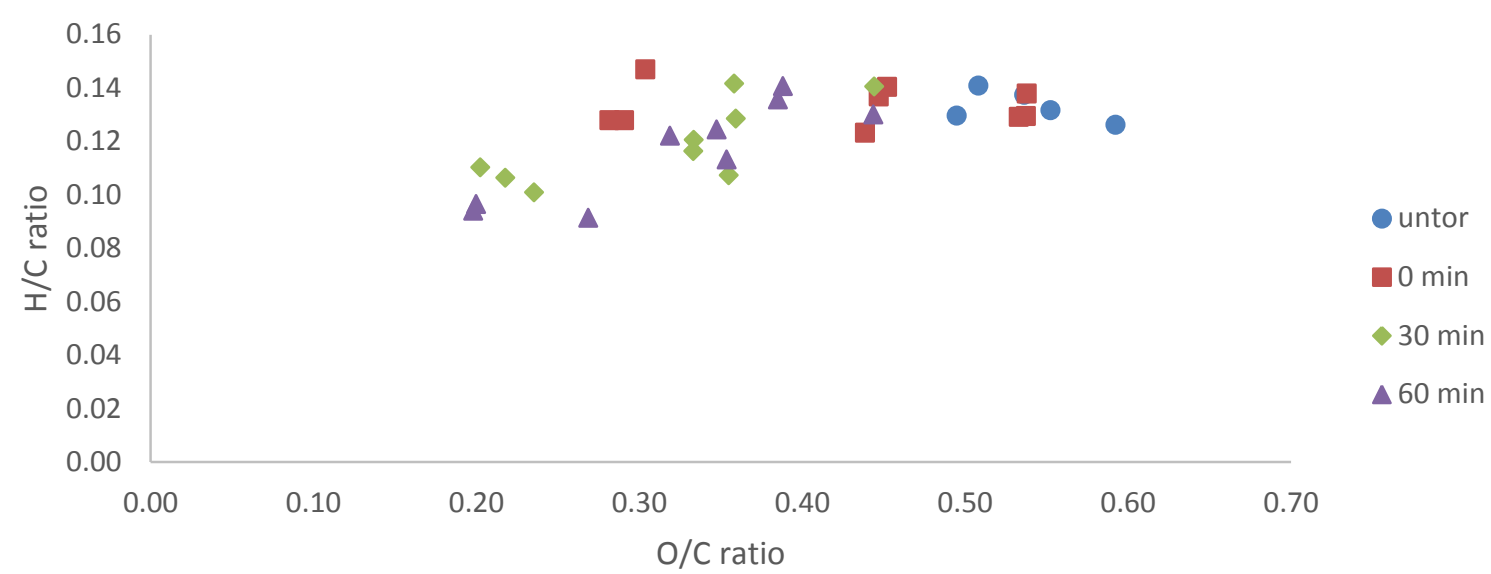

(b)

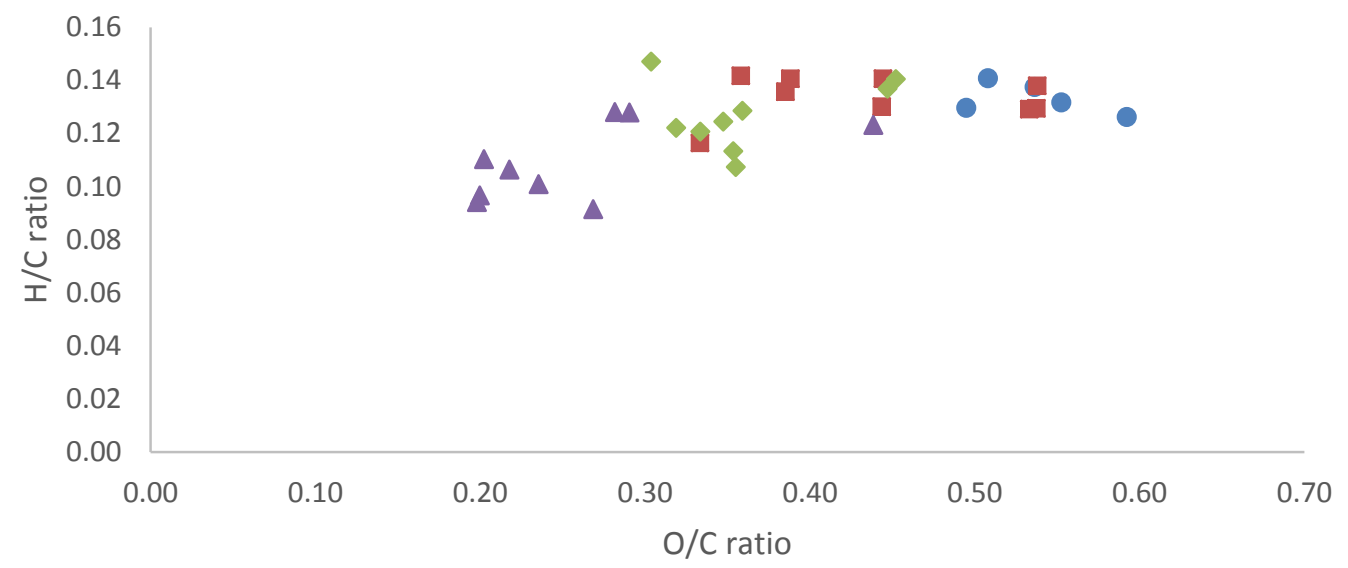

(c)

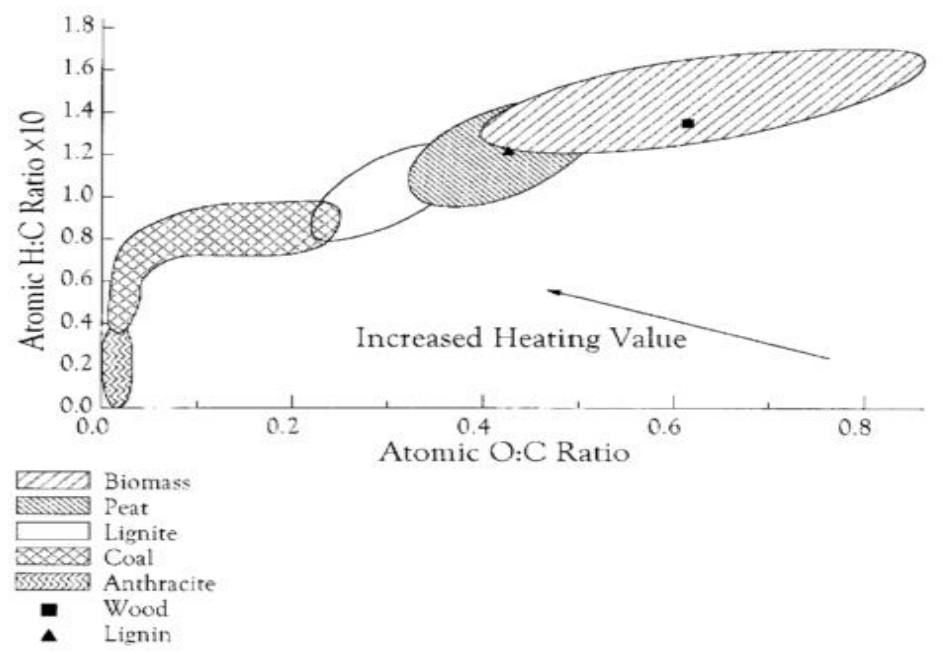

Fig. 5. van Krevelen diagrams of (a) torrefied Jatropha seed cake grouped by holding time, (b) torrefied Jatopha seed cake grouped by temperature, (c) various solid fuels [31]. 


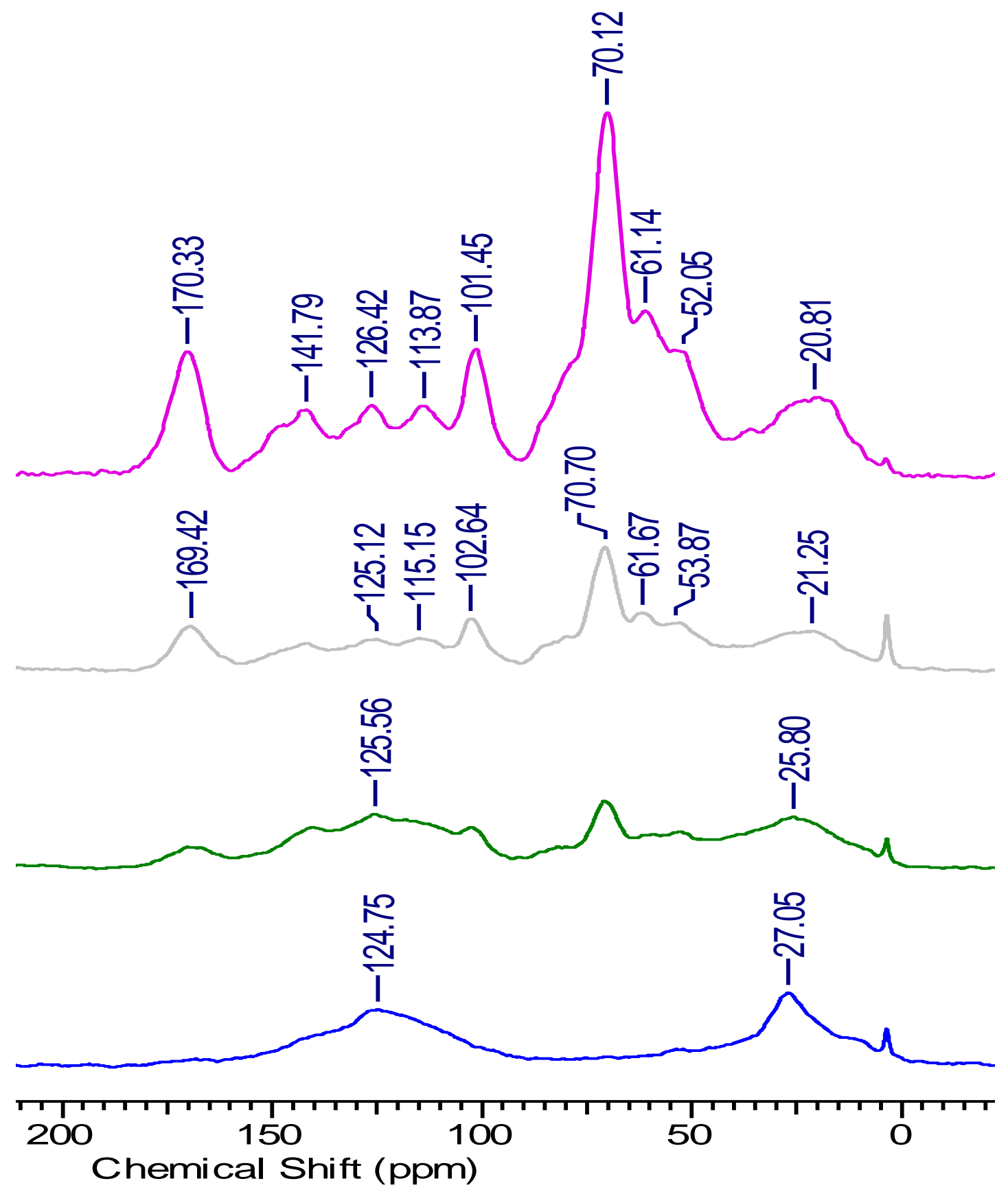

Fig. 6. ${ }^{13} \mathrm{C}$ NMR spectra for (a) untorrefied Jatropha seed cake and Jatropha seed cake torrefied for $60 \mathrm{~min}$ at (b) $200^{\circ} \mathrm{C}$, (c) $250^{\circ} \mathrm{C}$, (d) $300^{\circ} \mathrm{C}$. 
(a)

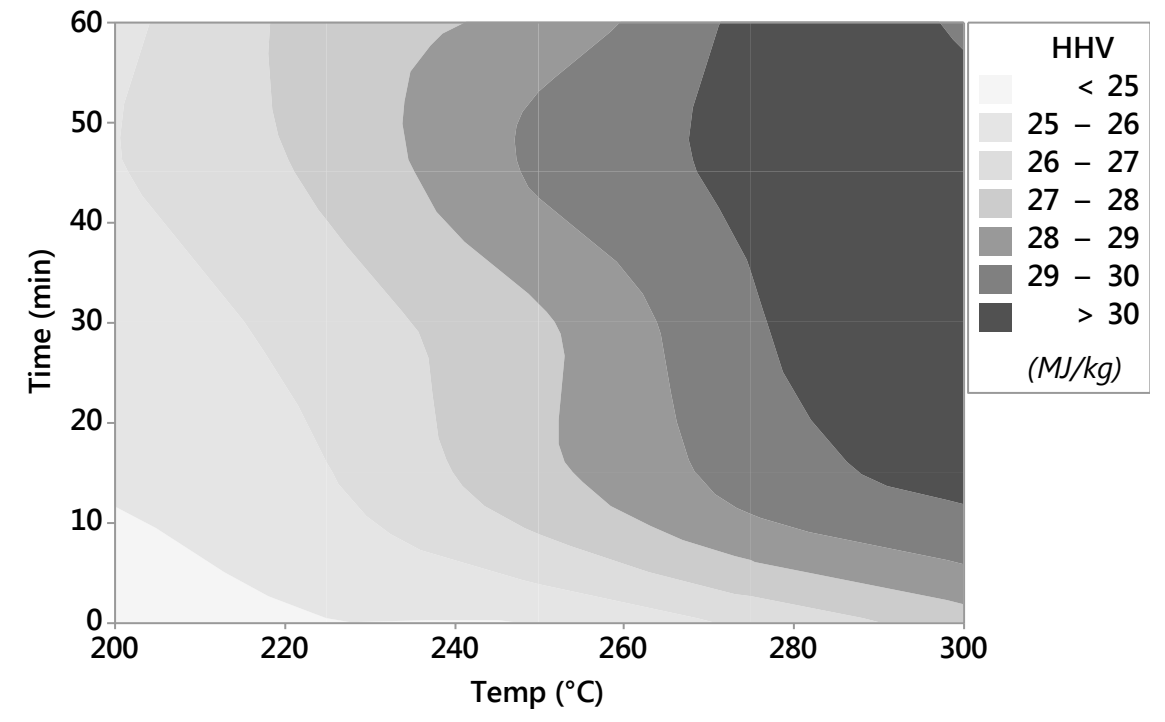

(b)

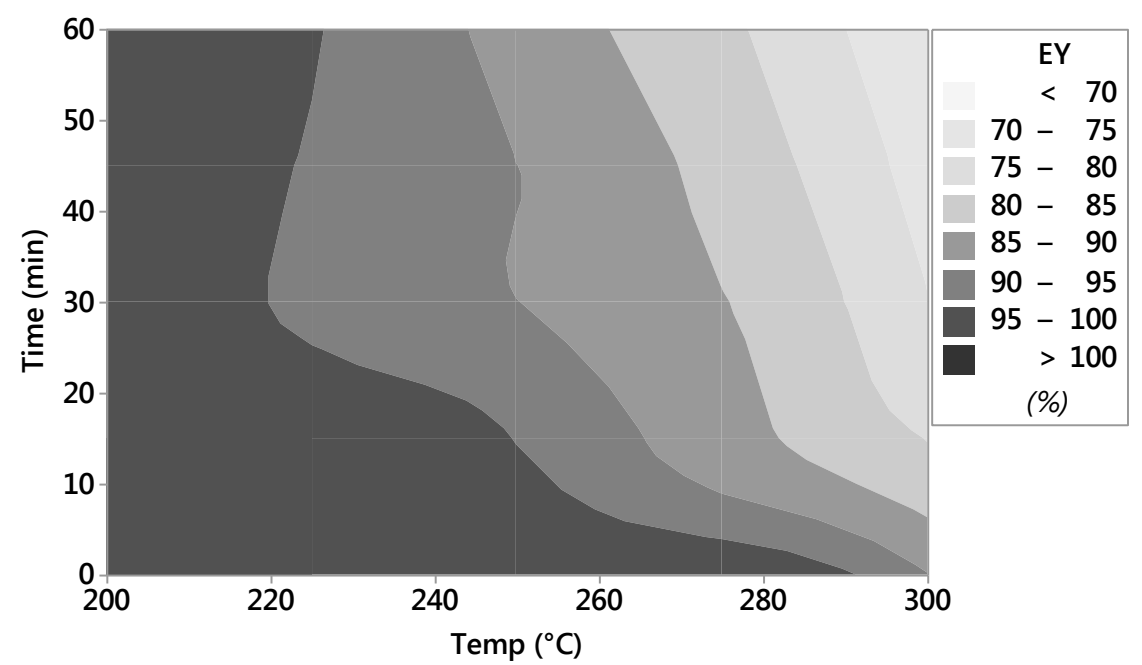

(c)

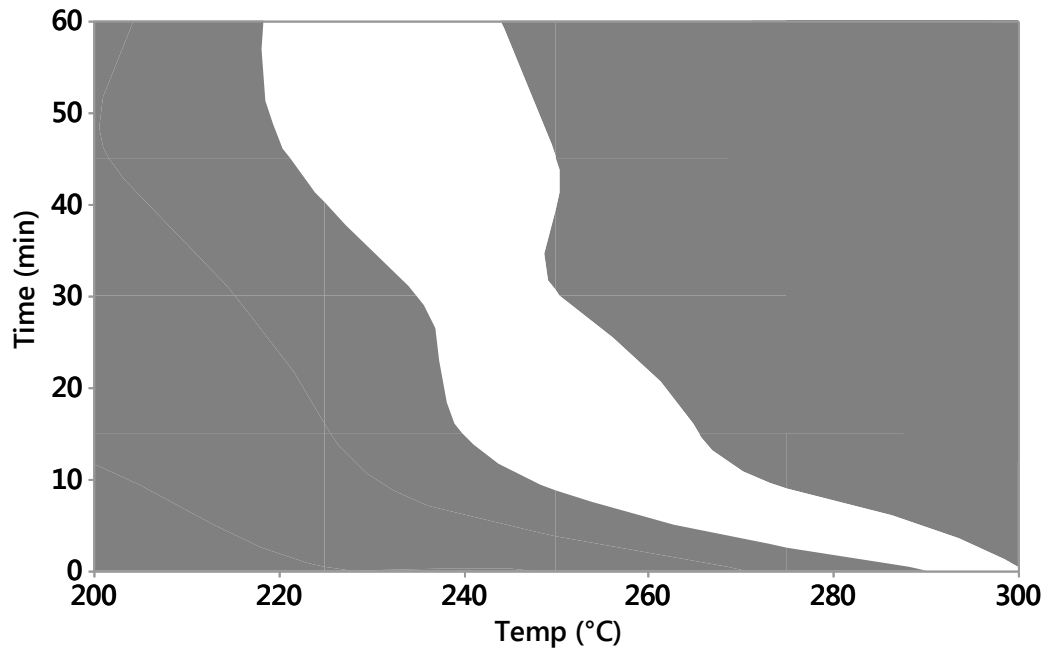

Fig. 7. Contour plots of (a) HHV, (b) energy yield, (c) overlay of HHV and energy yield $(\mathrm{EY})$. 